\title{
Yerel Kuru Fasulye (Phaseolus vulgaris L.) Genotiplerinin Tane Verimi, Verim Unsurları ve Bazı Kalite Özelliklerinin Belirlenmesi
}

\section{Abdulveli SIRAT ${ }^{* 1}$ \\ ${ }^{1}$ Gümüşhane Üniversitesi Şiran Mustafa Beyaz MYO, Şiran-Gümüşhane}

Öz: Bu araştırma, karasal iklimlerin karakteristik özelliğini taşıyan Gümüşhane ili Şiran ekolojik koşullarında Orta ve Doğu Karadeniz Bölgesinden toplanan 12 yerel fasulye genotipinin tane verimi, verim unsurları ve bazı kalite özelliklerini belirlemek için yürütülmüştür. Deneme 2017 ve 2018 yıllarında Tesadüf Blokları Deneme Desenine göre üç tekrarlamalı olarak kurulmuştur. İki yıl ortalamalarına göre, ekimden çiçeklenme başlangııına kadar geçen sürenin 39.30-45.40 gün, hasat olgunluk süresinin 113.33-120.17 gün, bitki boyunun 56.32-60.67 cm, ilk bakla yüksekliğinin 10.54-11.50 cm, bitkide bakla sayısının 9.47-10.45 adet, bakla uzunluğunun 7.35-10.29 cm, baklada tane sayısının 2.95-5.77 adet, tane verimi 185.07-277.68 $\mathrm{kg} \mathrm{da}^{-1}, 100$ tane ağırlı̆̆ının 32.27-43.00 g ve protein oranının \%18.97-24.32 arasında değiştiği tespit edilmiştir. En yüksek dekara tane verimleri GF1 $\left(277.68 \mathrm{~kg} \mathrm{da}^{-1}\right)$ ve GF2 $\left(273.74 \mathrm{~kg} \mathrm{da}^{-1}\right)$ genotiplerinden elde edilmiştir. Bu genotipler çiçeklenme başlangııı ve hasat olgunluk süresi bakımından daha erkenci oldukları tespit edilmiştir. Ayrıca bu genotipler bitkide bakla sayısı, bakla uzunluğu, baklada tane sayısı, 100 tane ağırlığı ve protein oranı açısından da en yüksek değere sahip olmuşlardır. Bu nedenle Gümüşhane-Şiran ekolojisine benzer şartlarda GF1 ve GF2 genotiplerin yetiştirilmesi önerilmektedir.

Anahtar Kelimeler: Fasulye verimi, genotip, kalite, korelasyon

\section{Determination of Grain Yield, Yield Components and Some Quality Traits of Local Dried Bean (Phaseolus vulgaris L.) Genotypes}

\begin{abstract}
This research was carried out to determine the grain yield, yield components and some quality characteristics of 12 local bean genotypes collected from the Central and Eastern Black Sea Region in the Siran ecological conditions of Gumushane province, which is characteristic of the continental climates. Trial was established in 2017 and 2018 in three repetitions according to the Trial Blocks Coincidence Pattern. According to the averages of two years, it was determined that means were ranged between 39.30-45.40 days from sowing to first flowering, 113.33-120.17 days for seed harvest maturity, $56.32-60.67 \mathrm{~cm}$ for plant height, $10.54-11.50 \mathrm{~cm}$ for the first pod height, 9.47-10.45 pods/plant for pods number per plant, 7.35-10.29 cm for pod length, 2.95-5.77 seeds/pod for seeds number per pod, grain yield 185.07-277.68 kg da-1,32.27-43.00 g for one hundred seeds weight and 18.97-24.32\% for crude protein content. The highest yield per decare was obtained from the genotypes GF1 (277.68 kg da $\left.{ }^{-1}\right)$ and GF2 (273.74 kg da $\left.{ }^{-1}\right)$. These genotypes were found to be earlier in terms of flowering onset and harvest maturity time. In addition, these genotypes had the highest values in terms of pod number, pod length, pod number in pod, 100 grain weight and protein ratio. For this reason, it is recommended to cultivate genotypes GF1 and GF2 under conditions similar to the Gumuşhane-Siran ecology.
\end{abstract}

Keywords: Bean yield, genotypes, quality, correlation

\section{GiRiş}

Orta Amerika ile Güney Amerika fasulyenin gen merkezi olup (Kwak ve Gepts, 2009), Güney ve Doğu Afrika, Güney Doğu ve Batı Avrupa, Kuzey, Orta ve Güney Amerika ile Doğu Asya olmak üzere beş bölgede fasulye üretimi yapılmaktadır (Demircan, 2018). Fasulye, yüksek protein içeriği ve lezzetli olması nedeniyle dünyada ve ülkemizde taze, konserve, taze tane ve kuru tane olarak yaygın bir şekilde tüketilmektedir. Kuru tanelerinde \%23-34 protein, \%60 karbonhidrat, \%5 ham selüloz, \%1.7 yağ ve \%3.6 kül bulunmaktadır. Özellikle yüksek protein içeriği nedeniyle ülkemizin hayvansal protein açığını kapatabilecek baklagil bitkilerinden birisidir (Abacı ve Kaya, 2018). Ayrıca taneleri potasyum, fosfor, kalsiyum, magnezyum, kükürt, demir ve mangan mineralleri yönünden, $A, B$ ve $D$ vitaminlerince oldukça zengin bir bitkidir (Şehirali, 1988; Pekşen ve Artık, 2005).

Kuru fasulye, özellikle gelişmekte olan ülkelerde insanların beslenmesinde temel besin kaynağı oluşturmakta, biyolojik azot fiksasyonu yoluyla toprağa bağladığı azot (64 $\mathrm{kg} \mathrm{da}^{-1}$ ) (Kün ve ark., 2005) ile kendinden sonraki bitkinin azot ihtiyacına destek olmakta ve bu özellikleri ile sebze yetiştiren çiftçilerin ekim nöbetinde vazgeçemedikleri bitkileri arasında yer almaktadır (Demircan, 2018). Ayrıca yüksek oranda protein içeriğine sahip fasulye samanı (Şehirali, 1988), hayvancılık açısından da önemli bir kaba yem kaynağıdır.

Fasulye, dünyada yaklaşık 34.5 milyon hektar ekim alanı, $882 \mathrm{~kg} \mathrm{ha}^{-1}$ verim ve 30.4 milyon ton üretim (Anonim, 2018) miktarı ile yemeklik baklagiller içerisinde ilk sırada yer almaktadır. Ülkemizde ise yaklaşık 88.9 bin ha ekim alanı ve 225 bin ton (Anonim, 2019) üretimle nohut ve mercimekten sonra üçüncü sırada yer almaktadır. Türkiye'de, kuru

Sorumlu Yazar: awsirat@hotmail.com

Geliş Tarihi: 30 Mayıs 2020

Kabul Tarihi: 5 Ekim 2020 
fasulye verimi, $2.53 \mathrm{t} \mathrm{ha}^{-1}$ ile dünya ortalamasının üzerindedir (Anonim, 2019). Gümüşhane ilinde, yaklaşık 1900 hektar alandan 3600 ton kuru fasulye üretimi yapılmaktadır (Anonim, 2019). Buradan, Gümüşhane'nin kuru fasulye verimi (1.89 $\left.\mathrm{t} \mathrm{ha}^{-1}\right)$ bakımından, ülke ortalamasının altında kaldığı ve verimi arttırmak için bilimsel ve modern yöntemlere gereksinim duyulduğu anlaşılmaktadır.

Fasulyenin ülkemize ne zaman ve kimin tarafından getirildiği hakkında resmi bir kayıt bulunmamakla birlikte 17. yüzyılda ülkemize girdiği (Bozoğlu ve Sözen, 2007) ve fasulyenin ülkemizde 250 yıldan beri yetiştirilmekte olduğu bildirilmektedir (Çalışkan, 2014; Adak ve ark., 2015). Fasulye, bünyesinde bulundurduğu yüksek protein miktarı ile insan beslenmesinde önemli bir baklagil bitkisidir. Diğer yemeklik baklagillerde tüketim alışkanlıkları yörelere göre değişmekle beraber fasulye hemen hemen her bölgede aynı yaygınlıkla tüketilen milli yemeklerimizin arasında yer alan bir üründür. Bunun yanı sıra ülkemizde tarımının 250 yıllık bir geçmişi olmasına rağmen özellikle Karadeniz Bölgesi'nde mikro gen merkezi yaratacak kadar çeşitlilik göstermiş bir bitkidir. Ayrıca bölgemizde geleneksel olarak küçük alanlarda uygulanan karışık ekim sistemi içerisinde de vazgeçilmez bir üründür (Özçelik ve Sözen, 2009).

Bu çalışmanın amacı özetle; Gümüşhane, karasal iklim ile Doğu Karadeniz iklimi arasında bir geçiş özelliği göstermektedir. Kelkit Vadisi'nin yükselti ve iklimsel yapısındaki çeşitliliğine ilave olarak, coğrafi geçiş bölgesinde yer alması, bölgenin doğal kaynaklarının ve biyolojik çeşitliliğinin çok yüksek olmasını beraberinde getirmiştir. Bu bölgede yetiştirilen tarla bitkileri arasında yer alan kuru fasulye bölge çiftçisi için vazgeçilmez bir üründür. Bölgenin farklı iklim yapısındaki çeşitliliği ve bereketli toprakları yerel kuru fasulye popülasyonlarında çeşitliliği artırmış ve özellikle şeker tane tipindeki formlar lezzetliliği ile iç piyasada öne çıkmıştır. Bölgemizde kuru fasulye yetiştiriciliği yapan çiftçiler kendi yerel popülasyonlarını ekmektedirler. Bölgemizde geleneksel olarak küçük alanlarda uygulanan karışık ekim sistemi içerisinde de vazgeçilmez bir üründür. Karadeniz Bölgesi'nde mikro gen merkezi oluşturacak kadar çeşitlilik göstermiş bir bitkidir. Gümüşhane'nin kuru fasulye verimi bakımından, ülke ortalamasının altında kaldığı ve verimi arttırmak için bilimsel ve modern yöntemlere gereksinim duyulduğu anlaşılmaktadır. Ülkemizde çok sayıda tescil edilmiş fasulye çeşidi bulunmasına rağmen, bölgemiz için henüz tescil edilmiş çeşit bulunmamaktadır. Dolayısıyla, bölgede daha sonra yapılacak çalışmalar için, bu genotiplerin özelliklerinin ayrıntılı olarak ortaya konulması durumunda ebeveyn olarak kullanılma olanakları hakkında da bilgi edinilmiş olacaktır. Bölgenin doğal yapısı itibariyle hayvancılığın özel bir önem taşıması ve bölgede tarıma dayalı sanayinin yeterince gelişmemiş olması sebebiyle, hayvan beslenmesinde yüksek oranda protein içeriğine sahip fasulye samanının kaba yem olarak değerlendirildiği görülmektedir. Fasulye ıslahında istenilen düzeyde kaliteli ve yüksek verim potansiyeline sahip çeşitlerin belirlenmesinde, genotip $\times$ çevre ilişkileri ile yakından ilgilenmekteki amaç değişik çevre şartlarına uygun ve çevre varyasyonundan en az etkilenen bir genetik yapıya sahip fasulye çeşitlerinin bilinmesidir. Dolayısıyla, yukarıda belirtilen nedenlerden dolayı bu araştırma Gümüşhane Şiran koşullarında, Orta ve Doğu Karadeniz Bölgesinden toplanan 12 farklı fasulye genotiplerinin tane verimleri ve verimle ilgili özelliklerini belirleyerek, bölge koşullarına uygun genotip ya da genotipler tespit edilmeye çalışımıştır.

\section{MATERYAL VE YÖNTEM}

Bu araştırma, 2017 ve 2018 yıllarında Gümüşhane ili Şiran ekolojik koşullarında çiftçi arazisinde yürütülmüştür. Deneme alanının toprak analiz sonuçlarına göre; her iki yılda da topraklarının killi tınlı bünyeye ve hafif alkalin reaksiyona sahip, tuzsuz, orta kireçli, fosforca orta, potasyumca yeterli ve organik madde içeriği yönünden de iyi durumda olduğu tespit edilmiştir (Çizelge 1).

Fasulye yetiştirme periyodu dikkate alındığında, Gümüşhane ilinde uzun yılların ortalaması toplam 246,9 $\mathrm{mm}$ yağış düştüğü, en yüksek aylık toplam yağışın $118.4 \mathrm{~mm}$ ile Mayıs ayında, en düşük yağışın ise $12.2 \mathrm{~mm}$ ile Ağustos ayına ait olduğu görülmüştür (Çizelge 2). Denemenin yürütüldüğü 2017 ve 2018 yıllarında en düşük toplam yağış miktarı sırasıyla Temmuz $(0.0 \mathrm{~mm})$ ve Ağustos $(1.1 \mathrm{~mm})$ aylarında gerçekleşirken, en yüksek toplam yağış ise ekimlerin yapıldığı Mayıs ayında gerçekleşmiştir. Her iki deneme yılına ait aylık ortalama sıcaklık değerleri ve nem oranları uzun yıllar ortalaması ile büyük benzerlikler göstermiştir (Çizelge 2).

Çizelge 1. Deneme alanının topraklarına ait bazı fiziksel ve kimyasal özellikleri*

\begin{tabular}{|c|c|c|c|c|c|c|c|c|}
\hline YII & Analiz & $\begin{array}{l}\text { Doygunluk } \\
\text { (\%) }\end{array}$ & $\begin{array}{l}\text { Toplam } \\
\text { Tuz (\%) }\end{array}$ & PH & $\begin{array}{l}\mathrm{CaCO}_{3} \\
(\%)\end{array}$ & $\begin{array}{l}\mathrm{P}_{2} \mathrm{O}_{5} \\
\left(\mathrm{~kg} \mathrm{da}^{-1}\right)\end{array}$ & $\begin{array}{l}\mathrm{K}_{2} \mathrm{O} \\
\left(\mathrm{kg} \mathrm{da}^{-1}\right)\end{array}$ & $\begin{array}{l}\text { Organik } \\
\text { Madde (\%) }\end{array}$ \\
\hline \multirow{2}{*}{2017} & Değeri & 66.0 & 0.14 & 7.67 & 13.56 & 6.33 & 133.7 & 3.48 \\
\hline & Derecesi & Killi tınlı & Tuzsuz & Hafif alkalin & Orta kireçli & orta & Yeterli & İyi \\
\hline \multirow{2}{*}{2018} & Değeri & 54.0 & 0.06 & 8.01 & 11.33 & 7.48 & 122.4 & 3.62 \\
\hline & Derecesi & Killi tınlı & Tuzsuz & Hafif alkalin & Orta kireçli & orta & Yeterli & İyi \\
\hline
\end{tabular}

*Analizler Kahramanmaraş Sütçü İmam Üniversitesi, Ziraat Fakültesi, Toprak Bilimi ve Bitki Besleme Bölümü Laboratuvarında yapılmıştır 246 
Çizelge 2. Deneme yerine ait bazı meteorolojik veriler*

\begin{tabular}{|c|c|c|c|c|c|c|}
\hline Yillar & Mayıs & Haziran & Temmuz & Ağustos & Eylül & Ortalama/Toplam \\
\hline \multicolumn{7}{|c|}{ Toplam Yağış (mm) } \\
\hline 2017 & 74.7 & 32.3 & 0.0 & 13.7 & 2.0 & 122.7 \\
\hline 2018 & 117.4 & 86.4 & 15.8 & 1.1 & 28.1 & 248.8 \\
\hline Uzun Yıllar & 118.4 & 78.4 & 12.7 & 12.2 & 25.2 & 246.9 \\
\hline \multicolumn{7}{|c|}{ Ortalama Sıcaklık $\left({ }^{\circ} \mathrm{C}\right)$} \\
\hline 2017 & 13.4 & 17.8 & 21.8 & 23.3 & 20.2 & 19.30 \\
\hline 2018 & 15.2 & 18.7 & 21.8 & 21.3 & 17.9 & 18.98 \\
\hline Uzun Yıllar & 14.0 & 18.2 & 21.4 & 22.4 & 17.8 & 18.76 \\
\hline \multicolumn{7}{|c|}{ Ortalama Nem (\%) } \\
\hline 2017 & 57.7 & 55.4 & 47.9 & 50.9 & 39.1 & 50.20 \\
\hline 2018 & 63.6 & 61.7 & 54.6 & 51.4 & 56.0 & 57.46 \\
\hline Uzun Yıllar & 61.7 & 58.7 & 52.5 & 52.2 & 51.1 & 55.24 \\
\hline
\end{tabular}

*iklim verileri Gümüşhane Meteoroloji Müdürlüğünden alınmıştır Denemeler Tesadüf Blokları deneme desenine göre üç tekrarlamalı olarak kurulmuştur. Araştırmada toplanan 32 adet farklı fasulyeden, seçilmiş 12 şeker tane tipindeki yerel fasulye (bodur beyaz taneli) genotipi GF (Gümüşhane Fasulye) şeklinde kodlayarak materyal olarak kullanılmıştır (Çizelge 3). Ekimler sıra arası $50 \mathrm{~cm}$, sıra üzeri $10 \mathrm{~cm}$, sıraların uzunluğu $3 \mathrm{~m}$, her genotip 3 sıra olacak şekilde çiziler açılmış ve açılan çizilere 5-6 cm derinliğe, hava koşullarına bağlı olarak, ilk yıl 06.05.2017 tarihinde, ikinci yıl ise 11.05.2018 tarihinde elle ekilmiştir. Toprak analizi göz önüne alınarak ekimler sırasında $4 \mathrm{~kg}$ saf azot hesabıyla DAP'la gübreleme yapılmıştır. Deneme alanı gerek duyuldukça yabancı otlar çapa ile kontrol altına alınmıştır. Bitkilerin su ihtiyacını karşılamak üzere denemeye 3 kez su verilmiştir. Deneme parsellerinde gözlemler tohum hasadı olgunluğuna gelen ve tesadüfi olarak seçilen 10'ar bitkide bitki boyu $(\mathrm{cm})$, ilk bakla yüksekliği $(\mathrm{cm})$, bitkide bakla sayısı (adet/bitki), bakla uzunluğu $(\mathrm{cm})$, baklada tane sayısı (adet/bakla) belirlenmiştir. Daha sonra dekara tane verimi $\left(\mathrm{kg} \mathrm{da}^{-1}\right), 100$ tane ağırlığı $(\mathrm{g})$ ile tanede ham protein oranı belirlenmiştir (Akçin, 1971; Ceyhan, 2004).

Araştırmada elde edilen sonuçlar, JMP 7.0.2 istatistik paket programı kullanılarak, Tesadüf Blokları Deneme Desenine Çizelge 3. Denemede kullanılan fasulye genotipleri, temin edildikleri yerler

\begin{tabular}{lll}
\hline Genotip No & Genotip Adı & Genotiplerin Topladığı Yerler \\
\hline GF1 & 29-ŞRN-1(MRK) & Gümüşhane İli, Şiran İlçesi Merkez \\
GF2 & 29-KLKT-1(MRK) & Gümüşhane İli, Kelkit İlçesi Merkez \\
GF3 & 29-KÖS-1(MRK) & Gümüşhane İli, Köse İlçesi Merkez \\
GF4 & 29-TROL-1 (MRK) & Gümüşhane İli, Torul İlçesi Merkez \\
GF5 & 69-BYBRT-1(MRK) & Bayburt İli, Merkez \\
GF6 & 24-ERZNCN-1(MRK) & Erzincan İli, Merkez \\
GF7 & 61-TRBZN-1(MRK) & Trabzon İli, Merkez \\
GF8 & 61-MÇK-1(MRK) & Trabzon İli, Maçka İlçesi Merkez \\
GF9 & 53-RiZE-PZR-1(MRK) & Rize İli, Pazar İlçesi Merkez \\
GF10 & 28-DOGNKNT-1 & Giresun İli, Doğankent İlçesi Merkez \\
GF11 & 28-TRBOLU-1 & Giresun İli, Tirebolu İlçesi Merkez \\
GF12 & 28-ŞBNKRHSR-1 & Giresun İli, Şebinkarahisar İlçesi Merkez \\
\hline
\end{tabular}

göre analiz edilmiştir (Anonim, 2007). Çeşitler arasındaki etkili farklılıkları görmek LSD testi kullanılmıştır. İncelenen özellikler arasındaki ilişkileri ifade eden korelasyo analizi yine aynı paket program kullanılarak belirlenmiştir.

\section{BULGULAR VE TARTIŞMA}

Bu araştırma, Orta ve Doğu Karadeniz Bölgesinden toplanan 12 yerel fasulye genotipinin tane verimi ve verim unsurları ve bazı kalite özelliklerinin belirlemesi amacıyla Gümüşhane ili Şiran ekolojik koşullarında çiftçi arazisinde yürütülmüştür. Yapılan varyans analiz sonuçları Çizelge 4'te, özelliklere ait ortalamalar ve gruplandırmalar Çizelge 5, 6, 7 ve 8'de verilmiştir.

Çiçeklenme başlangıç süresi (gün): Araştırmada iki yılın ortalamalarına göre fasulye genotipleri arasında ekimden çiçeklenme başlangıcına kadar geçen süre bakımından istatistiksel olarak önemli $(P<0.01)$ fark bulunmuştur (Çizelge 4). Çiçeklenme başlangıç süresi 39.30-45.40 gün arasında değişmiştir. En erken çiçeklenme süresi GF2 (39.30 gün) nolu genootipte tespit edilmiş, bu genotipi istatistiksel olarak aynı grupta yer alan GF1 (39.35 gün), GF10 (39.72 gün), GF11 (39.97 gün) ve GF9 (40.24 gün) genotipler 
Yerel Kuru Fasulye (Phaseolus vulgaris L.) Genotiplerinin Tane Verimi, Verim Unsurları ve Bazı Kalite Özelliklerinin Belirlenmesi

Çizelge 4. Yerel kuru fasulye genotiplerinin verim ve verim özelliklere ait varyans analiz sonuçları

\begin{tabular}{|c|c|c|c|c|c|c|c|}
\hline VK & Genel & YII & Genotip & Yll $\times$ Genotip & Tekrar & Hata & DK (\%) \\
\hline SD & 71 & 1 & 11 & 11 & 4 & 44 & \\
\hline ÇBS & & 0.631 & $29.130 * *$ & 2.914 & 2.422 & 2.152 & 3.50 \\
\hline HOS & & 55.125 & $48.246^{* *}$ & $11.428^{* *}$ & 32.667 & 3.379 & 1.55 \\
\hline BB & & 24.851 & 9.424 & 12.861 & 45.960 & 13.859 & 6.33 \\
\hline İBY & & 2.806 & 0.648 & 0.561 & 0.680 & 1.535 & 11.44 \\
\hline BBS & & 3.556 & 0.669 & 0.298 & 3.861 & 1.656 & 12.96 \\
\hline BU & & $4.961^{*}$ & $6.117^{* *}$ & 0.301 & 0.332 & 0.552 & 8.65 \\
\hline BTS & & 5.951 & $3.874 * *$ & 0.287 & 1.564 & 0.258 & 12.94 \\
\hline TV & & $33484.4^{*}$ & $5308.41 * *$ & $1051.72^{* *}$ & 2649.1 & 221.49 & 6.61 \\
\hline YTA & & $164.409 *$ & $82.084^{* *}$ & 6.657 & 9.587 & 5.015 & 6.21 \\
\hline PO & & $17.111^{* *}$ & $17.454^{* *}$ & 0.440 & 0.786 & 3.308 & 8.65 \\
\hline
\end{tabular}

${ }^{*} \mathrm{P}<0.05$ ve ${ }^{* *} \mathrm{P}<0.01$ düzeyinde önemlidir. VK: Varyasyon kaynakları; SD: Serbestlik dereceleri; DK: Değişim katsayısı; ÇBS: Çiçeklenme başlangıç süresi (gün); HOS: Hasat olgunluk süresi (gün); BB: Bitki boyu (cm); ỉBY: İlk bakla yüksekliği (cm); BBS: Bitkide bakla sayısı (adet/bitki); BU: Bakla uzunluğu (cm); BTS: Baklada tane sayısı (adet/bakla); TV: Tane verimi (kg da ${ }^{-1}$ ); YTA: Yüz tane ağıllı̆ı (g); PO: Protein oranı (\%)

izlemiştir. En uzun çiçeklenme süresine GF6 (45.40 gün) ve GF5 (45.09 gün) nolu genotipler sahip olmuştur (Çizelge 5). Pekşen (2005) Samsun koşullarında bazı fasulye genotiplerinde 41.33-49.83 gün, Elkoca ve Çınar (2015) Erzurum ekolojik koşullarında 8 fasulye çeşidi ve 7 fasulye hattı ile yaptıkları çalışmada 34.0-67.7 gün, İyigün ve Kayan (2019) bazı fasulye genotiplerinin Eskişehir koşullarında 49.33-56.33 gün arasında değiştiğini bildirmişlerdir. Birçok araştırıı tarafından fasulyede genotip ve çevre şartlarına bağlı olarak çiçeklenme başlangıcına kadar geçen süresinde değişimler meydana geldiği bildirilmiştir (Pekşen, 2005; Elkoca ve Çınar, 2015).

Hasat olgunluk süresi (gün): Hasat olgunluk süreleri fasulye genotiplerinden önemli derecede $(\mathrm{P}<0.01)$ etkilenmiş
(Çizelge 4), 113.33-120.17 gün arasında değişim göstermiştir. Hasat olgunluk süreleri bakımından GF2 ve GF1 (sırasıyla 113.33 ve 114.34 gün) numaralı en erkenci genotipler olarak belirlenmiş, aralarında istatistiksel olarak önemli bir farklılık bulunmamıştır. Tohum hasat olgunluğuna en geç gelen GF6, GF8, GF7, GF12, GF9, GF3 ve GF5 nolu genotipler olmuş, diğer genotipler ise olgunluk süresi bakımından erken ve geç olgunlaşan bu iki grup arasında yer almışlardır (Çizelge 5). Tohum hasat olgunlaşma süreleri arasındaki çok önemli farklılık çeşitlerin genotipik özelliklerinin farklı olmasından kaynaklanmaktadır. Incelenen fenolojik özelliklerin hasat olgunluk süreleri bakımından yıl×genotip interaksiyonu çok önemli bulunmuştur (Çizelge 4, 5). Fasulyede hasat olgunluk

Çizelge 5. Yerel kuru fasulye genotiplerinin Gümüşhane-Şiran ekolojik koşullarında bazı özelliklerine ait ortalamalar

\begin{tabular}{|c|c|c|c|c|c|c|c|c|c|}
\hline \multirow{2}{*}{ Genotipler } & \multicolumn{3}{|c|}{$\begin{array}{l}\text { Çiçeklenme başlangıç } \\
\text { süresi (gün) }\end{array}$} & \multicolumn{3}{|c|}{$\begin{array}{l}\text { Hasat olgunluk süresi } \\
\text { (gün) }\end{array}$} & \multicolumn{3}{|c|}{$\begin{array}{l}\text { Bitki boyu } \\
\text { (cm) }\end{array}$} \\
\hline & 2017 & 2018 & Ortalama & 2017 & 2018 & Ortalama & 2017 & 2018 & Ortalama \\
\hline GF1 & 39.27 & 39.43 & $39.35 \mathrm{f}$ & $114.00 \mathrm{ijk}$ & $114.67 \mathrm{ljk}$ & 114.34 ef & 56.8 & 60.53 & 58.67 \\
\hline GF2 & 39.40 & 39.20 & $39.30 \mathrm{f}$ & $112.33 \mathrm{k}$ & $114.33 \mathrm{jk}$ & $113.33 \mathrm{f}$ & 57.17 & 55.47 & 56.32 \\
\hline GF3 & 43.07 & 42.63 & $42.85 \mathrm{~cd}$ & $121.33 \mathrm{a}-\mathrm{d}$ & 119.00 c-g & $120.17 \mathrm{ab}$ & 62.27 & 57.63 & 59.95 \\
\hline GF4 & 43.47 & 41.67 & $42.57 \mathrm{~cd}$ & $119.33 \mathrm{c}-\mathrm{g}$ & $117.33 \mathrm{f}$ - I & $118.33 \mathrm{bc}$ & 54.70 & 59.37 & 57.04 \\
\hline GF5 & 45.20 & 44.97 & $45.09 \mathrm{ab}$ & $120.33 b-f$ & 119.67 c-g & $120.00 \mathrm{ab}$ & 58.43 & 59.10 & 58.77 \\
\hline GF6 & 45.57 & 45.23 & $45.40 a^{* *}$ & 120.67 b-e & $121.67 \mathrm{abc}$ & $121.17 a^{* *}$ & 61.67 & 59.67 & 60.67 \\
\hline GF7 & 41.47 & 45.53 & $43.50 \mathrm{bc}$ & 118.00 e-h & $124.00 \mathrm{a}^{* *}$ & $121.00 \mathrm{a}$ & 58.83 & 59.57 & 59.20 \\
\hline GF8 & 43.43 & 43.50 & $43.47 \mathrm{bc}$ & $118.33 \mathrm{~d}-\mathrm{h}$ & $124.00 \mathrm{a}$ & $121.17 \mathrm{a}$ & 55.53 & 60.47 & 58.00 \\
\hline GF9 & 40.60 & 39.87 & 40.24 ef & $118.33 \mathrm{~d}-\mathrm{h}$ & $123.33 \mathrm{ab}$ & $120.83 a$ & 56.50 & 60.27 & 58.39 \\
\hline GF10 & 39.33 & 40.10 & $39.72 \mathrm{f}$ & 115.67 hıj & $116.67 \mathrm{~g}-\mathrm{j}$ & $116.17 \mathrm{de}$ & 58.77 & 61.23 & 60.00 \\
\hline GF11 & 39.67 & 40.27 & 39.97 ef & 115.67 hıj & $118.33 \mathrm{~d}-\mathrm{h}$ & $117.00 \mathrm{~cd}$ & 58.57 & 59.03 & 58.80 \\
\hline GF12 & 41.40 & 41.71 & $41.56 \mathrm{de}$ & $120.00 c-f$ & $122.00 \mathrm{abc}$ & $121.00 \mathrm{a}$ & 59.17 & 60.17 & 59.67 \\
\hline \multirow[t]{2}{*}{ Ortalama } & 41.82 & 42.01 & 41.92 & 117.83 & 119.58 & 118.71 & 58.20 & 59.38 & 58.79 \\
\hline & \multicolumn{3}{|c|}{ LSD genotip: 1.71} & \multicolumn{6}{|c|}{ LSD genotip: 2.14 yıl $\times$ genotip: 3.03} \\
\hline
\end{tabular}

Aynı harf ile gösterilen ortalamalar arasında ${ }^{*} \mathrm{P}<0.05,{ }^{*} \mathrm{P}<0.01$ olasılıkla fark yoktur 
99.17-120.00 gün arasında değiştiğini Pekşen (2005) bildirmiştir. Bozoğlu ve Gülümser (1999), fasulyede ekimden kuru tane hasadının yapıldığı zamana kadar geçen sürenin genotip, çevre ve genotip $\times$ çevre interaksiyonundan çok önemli derecede etkilendiğini ifade etmişlerdir.

Bitki boyu $(\mathbf{c m})$ : Kuru olgunlukta her parselden tesadüfi olarak alınan 10 bitkide toprak seviyesinden itibaren bitkinin en uç noktası arasındaki uzunluk $\mathrm{cm}$ cinsinden ölçülüp ortalaması alınmıştır. Denemede genotiplere ait bitki boylarının ortalamaları Çizelge 5 'te göstermiş olup, iki yılın ortalamasına göre en yüksek bitki boyu $(60.67 \mathrm{~cm}) \mathrm{GF6}$ nolu genotipinde, en kısa boy $(56.32 \mathrm{~cm})$ ise GF2 nolu genotipinde tespit edilmiştir. Denemenin birinci yılındaki düşük yağış miktarı bitki boylarını da etkilemiş olup ikinci yıla göre daha düşük bitki boyu tespit edilmiştir. Denemenin birinci yılında çeşitlerin bitki boyu ortalamaları $58.20 \mathrm{~cm}$, ikinci yılında $59.38 \mathrm{~cm}$ olarak belirlenmiştir (Çizelge 5). Bozoğlu ve Gülümser (1999) farklı çevrelerde yetiştirilen fasulye çeşit/hatlarının bitki boylarını $31.48-81.71 \mathrm{~cm}$, Pekşen (2005) Samsun koşullarında bazı fasulye genotiplerinin bitki boylarının 24.55-72.28 cm, Özçelik ve Sözen (2009), Kelkit Vadisi'nden toplanmış olanlarında tanımlama sırasında belirlenen bitki boylarının $48-70 \mathrm{~cm}$, Elkoca ve Çınar (2015) Erzurum ekolojik koşullarında 8 fasulye çeşidi ve 7 fasulye hattının bitki boyunu 37.7-50.5 $\mathrm{cm}$ arasında değiştiğini bildirmişlerdir. Fasulyede tane verimini etkileyen en önemli verim unsurlarının bitki boyu, bakla sayısı, bakladaki tane sayısı ve 1000 tane ağırlığı olduğu bildirilmiştir (Önder ve Şentürk, 1996; Pekşen ve Gülümser, 2005).

ilk bakla yüksekliği (cm): Kuru hasat döneminde toprak yüzeyinden itibaren ilk meyvenin bağlandığı boğuma kadar olan uzunluk olarak ölçülen ilk bakla yükseklikleri 10.54-
$11.50 \mathrm{~cm}$ arasında değişmiş ve genotipler arasında önemli farklılıklar göstermemiştir. En yüksek ilk bakla GF12, GF1 ve GF3 nolu genotiplerden (sırasıyla 11.50, 11.38 ve $11.04 \mathrm{~cm}$ ) elde edilmiştir. GF2, GF4, GF5, GF6, GF7, GF8, GF9, GF10 ve GF11 nolu genotipler toprak yüzeyinden en düşük ilk bakla yüksekliğine sahip olmuşlardır (Çizelge 6). Çalışmada belirlediğimiz ilk bakla yüksekliklerine ait değerler Anlarsal ve ark. (2000)'ın 13.3-18.1 cm ile Çakmak ve ark. (1999)'nın $15.80-18.55 \mathrm{~cm}$ arasında değişen ortalamalarına göre daha düşük bulunmuştur. Samsun koşullarında bazı fasulye genotiplerinin ilk bakla yüksekliği $6.90-12.65 \mathrm{~cm}$ arasında değiştiğini belirten Pekşen (2005)'nin değerleriyle uyum içindedir. Elkoca ve Çınar (2015) Erzurum ekolojik koşullarında 8 fasulye çeşidi ve 7 fasulye hattının ilk bakla yüksekliğinin 12.9-19.7 cm arasında değiştiğini bildirmişlerdir. Çeşit, yetiştirme tekniği ve çevre koşullarının ilk bakla yüksekliği üzerine önemli etkisi olduğu tespit edilmiştir (Önder ve Şentürk, 1996).

Bitkide bakla sayısı (adet/bitki): Bitki başına bakla sayıları 9.47-10.45 adet arasında değişmiş ve genotipler arasında istatistiki farklılıklar bulunmamıştır. Bitki başına en çok bakla sayısı GF1 (10.45 adet), GF2 (10.42 adet), GF10 (10.00 adet) ve GF11 (10.05) nolu genotiplerde belirlenmiştir. Bitkide bakla sayısı bakımından sırasıyla GF3, GF7, GF9, GF6, GF5, GF8 ve GF4 nolu genotipler olmuştur (Çizelge 6). Fasulyede bitki başına bakla sayısı 11.4-15.2 adet (Anlarsal ve ark., 2000), 7.21-13.45 adet (Pekşen, 2005), 7-43 adet (Sözen, 2012), 6.5-14.1 adet (Elkoca ve Çınar, 2015) arasında değiştiğini bildirmişlerdir. Düzdemir ve Akdağ (2001) bitkide bakla sayısının genotiplere göre önemli düzeyde varyasyon (8.6-26.2 adet) gösterdiğini beyan etmişlerdir. Bozoğlu ve Gülümser (2000) ve Babagil ve ark. (2011) ise bitkide bakla sayısının genotip ve çevre koşullarına bağı olarak değiştiğini bildirmektedirler.

Çizelge 6. Yerel kuru fasulye genotiplerinin Gümüşhane-Şiran ekolojik koşullarında bazı morfolojik özelliklerine ait ortalamalar

\begin{tabular}{|c|c|c|c|c|c|c|c|c|c|}
\hline \multirow{2}{*}{ Genotipler } & \multicolumn{3}{|c|}{ ilk bakla yüksekliği (cm) } & \multicolumn{3}{|c|}{ Bitkide bakla sayısı (adet/bitki) } & \multicolumn{3}{|c|}{ Bakla uzunluğu $(\mathrm{cm})$} \\
\hline & 2017 & 2018 & Ortalama & 2017 & 2018 & Ortalama & 2017 & 2018 & Ortalama \\
\hline GF1 & 10.83 & 11.93 & 11.38 & 10.43 & 10.47 & 10.45 & 10.17 & 10.40 & $10.29 a^{* *}$ \\
\hline GF2 & 10.40 & 10.80 & 10.60 & 10.40 & 10.43 & 10.42 & 9.67 & 10.07 & $9.87 \mathrm{a}$ \\
\hline GF3 & 10.60 & 11.47 & 11.04 & 9.73 & 10.20 & 9.97 & 8.57 & 8.73 & $8.65 \mathrm{~b}$ \\
\hline GF4 & 11.23 & 10.37 & 10.80 & 9.23 & 9.70 & 9.47 & 7.30 & 8.83 & $8.07 \mathrm{bc}$ \\
\hline GF5 & 10.47 & 10.67 & 10.57 & 8.83 & 10.33 & 9.58 & 7.47 & 8.37 & $7.92 \mathrm{bc}$ \\
\hline GF6 & 10.60 & 10.60 & 10.60 & 9.20 & 10.07 & 9.64 & 7.63 & 7.90 & $7.77 \mathrm{c}$ \\
\hline GF7 & 9.93 & 11.30 & 10.62 & 9.83 & 10.07 & 9.95 & 7.83 & 8.43 & $8.13 b c$ \\
\hline GF8 & 10.43 & 10.67 & 10.55 & 9.43 & 9.67 & 9.55 & 7.13 & 8.13 & $7.63 \mathrm{c}$ \\
\hline GF9 & 10.50 & 10.57 & 10.54 & 9.37 & 10.23 & 9.80 & 8.07 & 7.97 & $8.02 \mathrm{bc}$ \\
\hline GF10 & 10.83 & 10.90 & 10.87 & 10.17 & 10.37 & 10.27 & 9.30 & 10.00 & $9.65 \mathrm{a}$ \\
\hline GF11 & 10.37 & 11.40 & 10.89 & 9.77 & 10.23 & 10.00 & 9.53 & 9.83 & $9.68 \mathrm{a}$ \\
\hline GF12 & 11.37 & 11.63 & 11.50 & 10.07 & 10.03 & 10.05 & 7.20 & 7.50 & $7.35 \mathrm{c}$ \\
\hline \multirow[t]{2}{*}{ Ortalama } & 10.63 & 11.03 & 10.83 & 9.71 & 10.15 & 9.93 & $8.32 b$ & $8.85 a^{*}$ & 8.58 \\
\hline & & & & & & & \multicolumn{2}{|c|}{ LSD genotip: 0.86} & yıl: 0.38 \\
\hline
\end{tabular}

Aynı harf ile gösterilen ortalamalar arasında ${ }^{*} P<0.05,{ }^{* *} P<0.01$ olasılıkla fark yoktur 
Bozoğlu ve Gülümser (1999) fasulyede tane verimi ile bitkide bakla sayısı, biyolojik verim, 1000 tane ağırlığı, bitki boyu, hasat indeksi, tane büyüklük indeksi ve çiçeklenme periyodu ile olumlu ve çok önemli ikili ilişkiler olduğunu belirlemişlerdir.

Bakla uzunluğu $(\mathbf{c m})$ : Deneme parselinin her sırasından hasat edilen bitkilerden tesadüfi olarak seçilen 10 baklanın uzunluğu ölçülüp cm olarak tespit edilmiştir. Genotiplerin bakla uzunluğu istatistiksel olarak farklı önemli $(P<0.01)$ bulunmuştur (Çizelge 4). En uzun baklaların GF1 (10.29 cm), GF2 $(9.87 \mathrm{~cm})$, GF11 $(9.68 \mathrm{~cm})$ ve GF10 $(9.65 \mathrm{~cm})$ nolu genotiplerde olduğu belirlenmiştir (Çizelge 6). Denemelerde yıllar arsındaki farklılık da önemli $(P<0.05)$ bulunmuş, ikinci yıla ait bakla uzunluğu birinci yıla göre daha yüksek bulunmuştur (Çizelge 6). Belirlenen bakla uzunluğuna ait değerler Çiftçi ve Şehirali (1984), Akdağ ve Şahin (1994), Düzdemir ve Akdağ (2001)'nın bulgularıyla benzerlik göstermektedir. Ancak Karasu (1988)'nun Bursa yöresinde 4 fasulye çeşidinde yaptığı çalışma sonucunda elde ettiği bakla uzunlukları değerlerinden (10.83-13.16 cm) daha düşük bulunmuştur. Bakla uzunluğu, çeşidin özelliklerinden olup, çevre şartları ve yetiştirme yöntemlerinden de etkilenmektedir (Karasu, 1988; Pekşen 2005).

Baklada tane sayısı (adet/bakla): Parsellerden tesadüfi olarak 10 bitki alınıp, her bitkiden rastgele 10 baklanın taneleri sayılarak ortalaması alınmış ve adet olarak belirlenmiştir. Baklada tane sayıları fasulye genotiplere göre 2.95-5.77 adet arasında değişmiş olup, farklılık $\mathrm{P}<0.01$ düzeyinde önemli bulunmuştur (Çizelge 4). İki yılın ortalaması olarak en yüksek baklada tane sayısı 5.77 adet ile GF1 nolu genotipinden elde edilirken, en düşük baklada tane sayısı ise 2.95 adet ile GF12 nolu genotipinden elde edilmiş olup, bunu istatistik olarak aynı grupta yer alan sırası ile GF4 (3.47 adet), GF6 (3.38 adet), GF7 (3.29 adet) ve GF8 (3.30 adet) nolu genotipler izlemiştir (Çizelge 7).

Ülkemizde yürütülen farklı çalışmalarda baklada tane sayısı değişimleri Çukurova koşullarında 2.3-3.0 adet (Anlarsal ve ark., 2000), Erzurum ekolojik koşullarında 3.5-4.2 adet (Elkoca ve Kantar, 2004), Konya koşullarında 4.0-6.0 adet (Ceyhan ve ark., 2009), Erzurum koşullarında 3.47-5.07 adet (Elkoca ve Çınar, 2015) olarak bildirilmiştir. Babagil ve ark. (2011) yapmış oldukları çalışmalarında baklada tane sayısının genetik yapı ile ilişkili olduğunu belirtmişlerdir. Diğer bazı araştırıcılar kalıtım derecesi yüksek bir karakter olan baklada tane sayısında çeşit ve genotiplere bağlı olarak önemli farklılıkların olabileceğini bildirilmişlerdir (Elkoca ve Kantar, 2004; Pekşen, 2005). Baklada tane sayısı genotip ve çevre koşullarına bağlı olarak değişmektedir (Şehirali, 1980; Bozoğlu ve Gülümser, 2000). Özellikle tozlanma döllenme sırasında yaşanan sıcaklık ve kuraklıktaki ekstrem şartlar yaşandığında yumurta hücrelerini döllenip tane bağlamasını yada döllense bile bakla içerisinde gelişememesine neden olabilmektedir.

Tane verimi ( $\left.\mathbf{k g ~} \mathbf{~ d a}^{-1}\right)$ : Verim parsellerden hasat edilen bitkiler harman edilip taneler tartılmış ve dekara çevrilerek kg cinsinden ifade edilmiştir. Dekara tane verimleri bakımından fasulye genotipleri, yıllar $(P<0.05)$ ile yılxgenotip interaksiyonu arasında istatistiksel olarak önemli $(P<0.01)$ farklılıklar tespit edilmiştir (Çizelge 4). Iki yılın ortalamasına göre en yüksek tane verimi ise $277.68 \mathrm{~kg}$ $\mathrm{da}^{-1}$ ile GF1 nolu genotipinden elde edilirken, bunu 273.74 $\mathrm{kg} \mathrm{da}^{-1}$ ile GF2 nolu genotipi izlemiştir. En düşük tane verimi ortalaması ise GF12 (185.07 kg da $\left.{ }^{-1}\right)$ nolu genotipinde belirlenmiştir (Çizelge 7). Denemenin ikinci yılındaki yüksek

Çizelge 7. Yerel kuru fasulye genotiplerinin Gümüşhane-Şiran ekolojik koşullarında baklada tane sayısı ve tane verimine ait ortalamalar

\begin{tabular}{|c|c|c|c|c|c|c|}
\hline \multirow{2}{*}{ Genotipler } & \multicolumn{3}{|c|}{ Baklada tane sayısı (adet/bakla) } & \multicolumn{3}{|c|}{ Tane verimi $\left(\mathrm{kg} \mathrm{da}^{-1}\right)$} \\
\hline & 2017 & 2018 & Ortalama & 2017 & 2018 & Ortalama \\
\hline GF1 & 5.17 & 6.37 & $5.77 a^{* *}$ & $251.13 \mathrm{~b}$ & $304.23 a^{* *}$ & $277.68 a^{* *}$ \\
\hline GF2 & 4.73 & 5.17 & $4.95 b$ & $245.50 \mathrm{~b}$ & $301.97 a$ & $273.74 \mathrm{a}$ \\
\hline GF3 & 4.00 & 4.13 & $4.07 \mathrm{~cd}$ & 205.37 efg & $230.70 \mathrm{bcd}$ & $218.04 \mathrm{c}$ \\
\hline GF4 & 3.07 & 3.87 & 3.47 ef & $213.53 c-f$ & 227.27 b-e & $220.40 \mathrm{c}$ \\
\hline GF5 & 3.50 & 4.63 & $4.07 \mathrm{~cd}$ & $195.47 \mathrm{fgh}$ & $246.27 b$ & 220.87 c \\
\hline GF6 & 2.93 & 3.83 & 3.38 ef & $183.17 \mathrm{gh}$ & $248.83 \mathrm{~b}$ & $216.00 \mathrm{c}$ \\
\hline GF7 & 3.30 & 3.27 & 3.29 ef & $180.03 \mathrm{~h}$ & $206.83 \mathrm{~d}-\mathrm{g}$ & $193.43 d$ \\
\hline GF8 & 3.10 & 3.50 & 3.30 ef & $184.40 \mathrm{gh}$ & $199.93 \mathrm{fgh}$ & $192.17 d$ \\
\hline GF9 & 3.63 & 3.53 & $3.58 \mathrm{de}$ & $201.90 \mathrm{fgh}$ & $233.93 \mathrm{bc}$ & $217.92 \mathrm{c}$ \\
\hline GF10 & 3.43 & 4.27 & 3.85 cde & $202.77 \mathrm{fgh}$ & $284.80 \mathrm{a}$ & $243.79 \mathrm{~b}$ \\
\hline GF11 & 4.00 & 4.83 & $4.42 \mathrm{bc}$ & $200.20 \mathrm{fgh}$ & $286.80 \mathrm{a}$ & $243.50 \mathrm{~b}$ \\
\hline GF12 & 2.77 & 3.13 & $2.95 \mathrm{f}$ & $180.33 \mathrm{~h}$ & $189.80 \mathrm{fgh}$ & $185.07 \mathrm{~d}$ \\
\hline \multirow[t]{2}{*}{ Ortalama } & 3.64 & 4.21 & 3.92 & $203.65 \mathrm{~b}$ & $246.78 a^{*}$ & 225.22 \\
\hline & \multicolumn{3}{|c|}{ LSD genotip: 0.59} & \multicolumn{3}{|c|}{ LSD genotip: 17.32, yıl: 33.68, yıl×genotip: 24.49} \\
\hline
\end{tabular}

Aynı harf ile gösterilen ortalamalar arasında $* \mathrm{P}<0.05,{ }^{*} \mathrm{P}<0.01$ olasılıkla fark yoktur 
yağış miktarı parsellerden alınan verimi etkilemiş olup birinci yıla göre daha yüksek verim elde edilmiştir. Denemenin birinci yılında $203.65 \mathrm{~kg} \mathrm{da}^{-1}$, ikinci yılında $246.78 \mathrm{~kg} \mathrm{da}^{-1}$ ve ortalama verim $225.22 \mathrm{~kg} \mathrm{da}^{-1}$ olarak belirlenmiştir. Bu durumun ikinci yıl ilk yıla nazaran yaklaşık 2 kat daha fazla yağış farklılığından kaynaklandığı düşünülmektedir (Çizelge 2). Tane verimi, genotip ile çevre faktörlerinin karşılıklı etkileşimi sonucu ortaya çıkan kompleks bir yapıya sahiptir (Paunovic ve ark., 2006). Fasulyede çok fazla faktörün genotiplerin verimliliği üzerinde etkili olduğunu ve verimi etkileyen en önemli özelliklerin başında genetik yapının geldiğini bildirilmiştir (Pekşen ve Gülümser, 2005; İyigün ve Kayan, 2019). Tane veriminin bitkide bakla sayısı, baklada tane sayısı, bakla uzunluğu ve 100 tane ağırlığına bağı olarak değiştiğini bildiren birçok araştırıcı (Şehirali, 1980; Amini ve ark., 2002) mevcuttur.

Ülkemizin değişik ekolojik koşullarında yürütülen denemelerde fasulye çeşitlerinden elde edilen tane verimleri, Tokat koşularında 81.0-191.7 kg da ${ }^{-1}$ (Akdağ ve Şahin, 1994), Karaman koşullarında 376-414 kg da (Önder ve Şentürk, 1996), Çukurova koşullarında 57.4-119.6 kg da ${ }^{-1}$ (Anlarsal ve ark., 2000), Samsun ekolojik koşullarında 100.60-231.62 kg da-1 (Pekşen, 2005), Konya koşullarında 111.2-299.4 kg da-1 (Ceyhan ve ark., 2009), Erzurum koşullarında 92.4-195.4 kg da ${ }^{-1}$ (Elkoca ve Çınar, 2015) olarak saptanmıştır.

Genotiplere bağlı olarak da dekara tane verimleri büyük değişiklik göstermektedir. Bozoğlu ve Gülümser (1999) fasulyede tane verimini farklı çevrelere göre 79.19-264.38 $\mathrm{kg} \mathrm{da}^{-1}$, çeşitlere göre de $162.7-237.7 \mathrm{~kg} \mathrm{da}^{-1}$ arasında tespit etmişlerdir. Düzdemir ve Akdağ (2001) 55 fasulye genotipinin tane verimlerinin 73.4 ile $205.9 \mathrm{~kg} \mathrm{da}^{-1}$ arasında değiştiğini bildirmişlerdir. Tane verimi üzerine genotip, çevre ve çevre $\times$ genotip interaksiyonunun etkisinin çok önemli olduğu belirtilmektedir (Şehirali, 1980; Bozoğlu ve Gülümser, 2000).

100 tane ağırlığı (g): Taneler kuruduktan sonra her parselden alınan ürün içinden rastgele dört adet 100 tane sayılarak tartılmış ve tartımların ortalamaları alınarak $\mathrm{g}$ olarak belirlenmiştir. Hasat sonrası denemede yapılan değerlendirme sonucunda yüz tane ağırlığına yıl $(P<0.05)$ ve genotiplerin etkisi önemli $(P<0,01)$ bulunmuştur (Çizelge 4$)$. Genotipler bakımından yüz tane ağırlığı 32.27-43.00 g değerleri arasında değişmiş, en yüksek değer ise GF1 (43.00 g) ve GF2 (42.35 g) nolu genotiplerde belirlenmiştir (Çizelge 8). Bu genotipler çiçeklenme başlangıç ve hasat olgunluk süreleri bakımından en kısa süreli olan genotipler olarak tespit edilmiştir. Buna rağmen tane olgunluğu ve dolgunluğu açısından iyi performansa gösteren, 100 tane ağırlığı de yüksek olan genotipler olmuştur. Tespit edilen bu farklılığın genotipler arasındaki genetik farklılıktan kaynaklanabileceği düşünülmektedir (Şehirali, 1988). İlk yıl 34.52 g olan ortalama yüz tane ağırlığının ikinci yıl 37.55 g olarak görülmektedir (Çizelge 8). Araştırmamızın birinci yılında toplam yağış daha az sıcaklık ise daha yüksektir (Çizelge 2). Yüz tane ağırlığı yüksek kalıtım derecesine sahip bir özellik olup çevre şartlarından özellikle de iklim ve toprak şartlarından çok fazla etkilenmektedir (Çiftçi ve Şehirali, 1984). Anlarsal ve ark. (2000) Çukurova koşullarında bazı fasulye çeşitleri ile yürüttükleri denemelerinde Haziran ve Temmuz aylarında artan sıcaklığa bağlı olarak, yüksek sıcaklığın fasulyede tanenin küçük ve cılız olmasına neden olduğunu bildirmişlerdir. Farklı araştırmacılar fasulyede yüz tane ağırlığının 22.3-33.6 g (Anlarsal ve ark., 2000), 17.78-52.88 g (Pekşen, 2005),

Çizelge 8. Yerel kuru fasulye genotiplerinin Gümüşhane-Şiran ekolojik koşullarında yüz tane ağırlığı ve tanede ham protein oranına ait ortalamalar

\begin{tabular}{lllllll}
\hline \multirow{2}{*}{ Genotipler } & \multicolumn{1}{l}{$\mathbf{1 0 0}$ tane ağırlı̆ı $\mathbf{~ ( g ) ~}$} & \multicolumn{5}{l}{ Ham Protein oranı (\%) } \\
\cline { 2 - 7 } & 2017 & 2018 & Ortalama & 2017 & 2018 & Ortalama \\
\hline GF1 & 43.17 & 42.83 & $43.00 \mathrm{a} *$ & 23.50 & 25.13 & $24.32 \mathrm{a} *$ \\
GF2 & 41.53 & 43.17 & $42.35 \mathrm{a}$ & 23.07 & 24.53 & $23.80 \mathrm{a}$ \\
GF3 & 32.70 & 35.57 & $34.14 \mathrm{~cd}$ & 18.83 & 20.63 & $19.73 \mathrm{~cd}$ \\
GF4 & 31.73 & 36.63 & $34.18 \mathrm{~cd}$ & 19.13 & 19.80 & $19.47 \mathrm{~d}$ \\
GF5 & 30.93 & 34.50 & $32.72 \mathrm{~cd}$ & 19.47 & 20.53 & $20.00 \mathrm{~cd}$ \\
GF6 & 32.63 & 31.90 & $32.27 \mathrm{~d}$ & 19.80 & 21.07 & $20.44 \mathrm{bcd}$ \\
GF7 & 31.57 & 35.27 & $33.42 \mathrm{~cd}$ & 20.17 & 20.90 & $20.54 \mathrm{bcd}$ \\
GF8 & 32.17 & 37.20 & $34.69 \mathrm{~cd}$ & 19.43 & 20.47 & $19.95 \mathrm{~cd}$ \\
GF9 & 32.50 & 37.93 & $35.22 \mathrm{c}$ & 20.80 & 21.07 & $20.94 \mathrm{bcd}$ \\
GF10 & 37.40 & 39.97 & $38.69 \mathrm{~b}$ & 21.17 & 22.20 & $21.69 \mathrm{bc}$ \\
GF11 & 37.43 & 39.53 & $38.48 \mathrm{~b}$ & 22.00 & 22.80 & $22.40 \mathrm{ab}$ \\
GF12 & 30.53 & 36.07 & $33.30 \mathrm{~cd}$ & 19.00 & 18.93 & $18.97 \mathrm{~d}$ \\
Ortalama & 34.52 & $37.55^{*}$ & 36.04 & $20.53 \mathrm{~b}$ & $21.51 \mathrm{a} * *$ & 21.02 \\
& LSD genotip: $2.60 \mathrm{yll}: 2.03$ & & LSD genotip: 2.12 & yıl: 0.58 \\
\hline
\end{tabular}

Aynı harf ile gösterilen ortalamalar arasında ${ }^{*} \mathrm{P}<0.05,{ }^{*} \mathrm{P}<0.01$ olasılıkla fark yoktur 
12.16-41.24 g (Sözen, 2012), 34.6-99.8 g (Elkoca ve Çınar, 2015) arasında değiştiğini bildirmişlerdir.

Tanede ham protein oranı (\%): Protein miktarı bakımından ele alınan fasulye genotiplerinin istatistiki olarak yıl ve genotip $(P<0.01)$ önemli, yılxgenotip interaksiyonu ise önemsiz bulunmuştur (Çizelge 4). Yılların ortalamalarına bakıldığında, protein oranı birinci yılda \%20.53 ve ikinci yılda \%21.51 olarak gerçekleşmiş olup, deneme ortalaması ise \%21.02 olmuştur. Denemede kullanılan fasulye genotiplerine ait protein miktarları incelendiğinde ortalama protein oranı \%18.97-24.32 değeri aralığında değişim göstermiştir (Çizelge 8). Çizelge 8'da da görüldüğü gibi GF1 nolu genotip \%24.32 ile en yüksek protein oranına sahip olurken bu genotipi istatistiksel olarak aynı grupta yer alan GF2 (\%23.80) ve GF11 (\%22.40) nolu genotipler izlemiştir. En düşük protein oranı GF12 (\%18.97) ve GF4 (\%19.47) nolu genotiplerde saptanmıştır. Bozoğlu (1995), kuru fasulyede bazı tarımsal özelliklerin genotipxçevre interaksiyonu ve katılım derecelerinin belirlenmesi adlı çalışmasında kullanılan çeşitlerde protein oranı \%21.42-24.85 arasında değiştiğini bildirmiştir. Protein oranı çevre şartlarından özelikle besin maddeleri ve bunların alınımından etkilenmekte, yeterli gübrelemenin yapılması da protein oranı ve kaliteyi artırmaktadır.

İncelenen özellikler arasındaki ilişkiler: Araştırmada incelenen özelliklere ilişkin iki yıllık sonuçlardan hesaplanan korelasyon katsayıları Çizelge 9'da verilmiştir. Çizelge incelendiğinde; tane verimiyle bitkide bakla sayısı $\left(r=0.310^{* *}\right)$, bakla uzunluğu $\left(r=0.590^{* *}\right)$, baklada tane sayısı $\left(r=0.770^{* *}\right)$, yüz tane ağırlığı $\left(r=0.620^{* *}\right)$ ve protein oranı $\left(r=0.560^{* *}\right)$ arasında pozitif ve önemli, çiçeklenme başlangıç süresi $\left(r=-0.308^{* *}\right)$ ve hasat olgunluk süresi $(r=-$ $350 * *)$ arasında ise negatif ve önemli bir ilişki görülürken, tane verimiyle bitki boyu ( $r=-0.080)$ ve ilk bakla yüksekliği
( $r=0.102$ ) arasında önemsiz bir ilişki olduğu saptanmıştır. Bozoğlu (1995) protein oranı ile tane verimi arasında $\left(0.149^{* *}\right)$ önemli ve olumlu ilişki, Shinde ve Dumbre (2001) yüz tane ağırlığı ile tane verimi arasında önemli ilişki olduğunu bildirmişlerdir. Pekşen ve Gülümser (2005) tane verimi ile bakla sayısı, bitkide tohum sayısı ve bakla uzunluğu arasında olumlu ve çok önemli ilişkiler bulmuştur.

\section{SONUÇ}

Gümüşhane, karasal iklim ile Doğu Karadeniz iklimi arasında bir geçiş özelliği göstermektedir. Kelkit Vadisi'nin yükselti ve iklimsel yapısındaki çeşitliliğine ilave olarak, coğrafi geçiş bölgesinde yer alması, bölgenin doğal kaynaklarının ve biyolojik çeşitliliğinin çok yüksek olmasını beraberinde getirmiştir. Bölgemizde kuru fasulye yetiştiriciliği yapan çiftçiler kendi yerel popülasyonlarını ekmektedirler. Gümüşhane'nin kuru fasulye verimi bakımından, ülke ortalamasının altında kaldığı ve verimi arttırmak için bilimsel ve modern yöntemlere gereksinim duyulduğu anlaşılmaktadır. Ülkemizde çok sayıda tescil edilmiş fasulye çeşidi bulunmasına rağmen, bölgemiz için henüz tescil edilmiş çeşit bulunmamaktadır. Dolayısıyla, bölgede daha sonra yapılacak çalışmalar için, bu genotiplerin özelliklerinin ayrıntılı olarak ortaya konulması durumunda ebeveyn olarak kullanılma olanakları hakkında da bilgi edinilmiş olacaktır. Bu çalışma, Orta ve Doğu Karadeniz Bölgesinden toplanan 12 yerel fasulye genotiplerinin tane verimi, verim unsurları ve bazı kalite özelliklerinin belirlemesi amacıyla 2017 ve 2018 yıllarında Gümüşhane ili Şiran ekolojik koşullarında yürütülmüştür. Bu araştırmadan elde edilen bulgulara göre; fasulye genotiplerinin verim ve bazı verim öğeleri yönünden önemli farklılıklar tespit edilmiştir. İki yıl yürütülen araştırma sonucuna göre çiçeklenme başlangıç süresi ve hasat olgunluk süresi bakımından en erkenci, tane verimi ve verimi olumlu olarak etkilediği belirlenen bitkide

Çizelge 9. Bazı yerel fasulye genotiplerinde incelenen özellikler arasındaki ilişkiler ve önemlilik seviyeleri

\begin{tabular}{|c|c|c|c|c|c|c|c|c|c|}
\hline $\begin{array}{l}\text { İncelenen } \\
\text { Karakterler }\end{array}$ & HOS & BB & їBY & BBS & BU & BTS & TV & YTA & HPO \\
\hline ÇBS & $0.510^{* *}$ & 0.010 & -0.134 & -0.194 & $-0.538 * *$ & $-0.387^{* *}$ & $-0.308^{* *}$ & $-0.612^{* *}$ & $-0.396 * *$ \\
\hline HOS & 1 & 0.223 & 0.090 & -0.126 & $-0.510 * *$ & $-0.430 * *$ & $-0.350 * *$ & $-0.530 * *$ & $-0.450 * *$ \\
\hline BB & & 1 & 0.057 & -0.010 & -0.016 & -0.092 & -0.080 & 0.008 & 0.019 \\
\hline İBY & & & 1 & 0.194 & 0.037 & 0.030 & 0.102 & 0.018 & 0.004 \\
\hline BBS & & & & 1 & 0.126 & $0.257^{*}$ & $0.310^{* *}$ & 0.220 & $0.288^{*}$ \\
\hline$B U$ & & & & & 1 & $0.608^{* *}$ & $0.590 * *$ & $0.715^{* *}$ & $0.615^{* *}$ \\
\hline BTS & & & & & & 1 & $0.770 * *$ & $0.623 * *$ & $0.513^{* *}$ \\
\hline TV & & & & & & & 1 & $0.620 * *$ & $0.560 * *$ \\
\hline YTA & & & & & & & & 1 & $0.613^{* *}$ \\
\hline
\end{tabular}

${ }^{*} \mathrm{P}<0.05$ ve ${ }^{* *} \mathrm{P}<0.01$ düzeyinde önemlidir. ÇBS: Çiçeklenme başlangıç süresi (gün); HOS: Hasat olgunluk süresi (gün); BB: Bitki boyu (cm); IBY: İlk bakla yüksekliği (cm); BBS: Bitkide bakla sayısı (adet/bitki); BU: Bakla uzunluğu (cm); BTS: Baklada tane sayısı (adet/bakla); TV: Tane verimi (kg da ${ }^{-1}$ ); YTA: Yüz tane ağırlı̆̆ (g); HPO: Ham Protein oranı (\%) 
bakla sayısı, bakla uzunluğu, baklada tane sayısı, 100 tane ağırlığı ve protein oranı açısından en yüksek değer GF1 ve GF2 nolu genotiplerden elde edilmiştir. Dolayısıyla yüksek performans gösteren GF1 ve GF2 nolu genotipler bölgede fasulye üretiminin artırılmasında katkısı olabileceği düşünülmektedir.

\section{TEŞEKKÜR}

Ondokuz Mayıs Üniversitesi Ziraat Fakültesi Öğretim Üyesi Prof. Dr. Hatice BOZOĞLU'na katkılarından dolayı teşekkür ederiz.

\section{KAYNAKLAR}

Abacı E, Kaya M (2018) Farklı Termal Suların Fasulye (Phaseolus vulgaris L.)'de Çimlenme ve Bazı Fide Gelişim Özelliklerine Etkileri. Süleyman Demirel Üniversitesi Ziraat Fakültesi Dergisi, 13(2) :1-6.

Adak MS, Kayan N, Benlioğlu B (2015) Yemeklik Tane Baklagiller Üretiminde Değişimler ve Yeni Arayışlar. Ziraat Mühendisliği VIII. Teknik Kongresi. 12-16 Ocak 2015, Ankara, 387-399.

Akçin A (1971) Erzurum Şartlarında Yetiştirilen Kuru Fasulye Çeşitlerinde Gübreleme, Ekim Zamanı ve Sıra Aralığının Tane Verimine Etkisi ile bu Çeşitlerin Bazı Fenolojik, Morfolojik ve Teknolojik Karakterleri Üzerinde Bir Araştırma. Doktora Tezi, Atatürk Üniversitesi, Erzurum.

Akdağ C, Şahin M (1994) Tokat Şartlarına Uygun Kuru Fasulye Çeşitlerinin Belirlenmesi Üzerine Bir Araştırma. Gaziosmanpaşa Üniversitesi Ziraat Fak. Dergisi, 11(1) : 101-111.

Amini A, Ghannadha M, Abd-Mishani C (2002) Genetic Diversity and Correlation Between Different Traits in Common Bean (Phaseolus vulgaris L.). Iranian Journal of Agricultural Science, 33(4) : 605-615.

Anlarsal AE, Yücel C, Özveren D (2000) Çukurova Koşullarında Bazı Fasulye (Phaseolus vulgaris L.) Çeşitlerinde Tane Verimi ve Verimle İlgili Özellikler ile bu Özellikler Arası İlişkilerin Saptanması. Turkish Jou. of Agriculture Forestry, 24:19-29.

Anonim (2007) 7.0.2, SAS Institute Inc., Cary, North Carolina 27513 (JMP), USA.

Anonim (2018) FAOSTAT (Crop Statistics). The Food and Agriculture Organization of the United Nations, Rome (FAO), http://www.fao.org/faostat/en/\#data/QC, (Erişim Tarihi: 29/04/2020).

Anonim (2019) Türkiye İstatistik Kurumu, Bitkisel Üretim İstatistikleri, Tahıllar ve Diğer Bitkisel Ürünler (Kuru Baklagiller-Tüik).

http://www.tuik.gov.tr/PreTablo.do?alt_id=1001.. (Erişim Tarihi: 29/04/2020).

Babagil GE, Tozlu E, Dizikısa T (2011) Erzincan ve Hınıs Ekolojik Koşullarında Yetiştirilen Bazı Kuru Fasulye (Phaseolus vulgaris L.) Genotiplerinin Verim ve Verim Unsurlarının Belirlenmesi. Atatürk Üniversitesi Ziraat Fakültesi Dergisi, 42(1) : 11-17.

Bozoğlu H (1995) Kuru Fasulyede (Phaseolus vulgaris L.) Bazı Tarımsal Özelliklerin Genotip $\times$ Çevre Interaksiyonu ve Katılım Derecelerinin Belirlenmesi Üzerine Bir Araştırma. Doktora Tezi, Ondokuz Mayıs Üniversitesi, Fen Bilimleri Enstitüsü, Samsun.
Bozoğlu H, Gülümser A (1999) Kuru Fasulyede (Phaseolus vulgaris L.) Bazı Tarımsal Özelliklerin Korelasyonları ve Kalıtım Derecelerinin Belirlenmesi. Türkiye 3. Tarla Bitkileri Kongresi, 15-18 Kasım 1999, Adana, 360-365.

Bozoğlu H, Gülümser A (2000) Kuru Fasulyede (Phaseolus vulgaris L.) Bazı Tarımsal Özelliklerin Genotip Çevre Interaksiyonları ve Stabilitelerinin Belirlenmesi Üzerine Bir Araştırma. Turkish Journal of Agriculture Forestry, 24: 211-220.

Bozoğlu H, Sözen Ö (2007) Some Agronomic Properties of the Local population of Comman Bean (Phaseolus vulgaris L.) of Artvin Province. Turkish Journal of Agricultural Forestry, 31: 327-334.

Ceyhan E (2004) Effects of Sowing Dates on Some Yield Components and Yield of Dry Bean (Phaseolus vulgaris L.) Cultivars. Turkish Journal of Field Crops, 9(2) : 87-95.

Ceyhan E, Önder M, Kahramani A (2009) Fasulye Genotiplerinin Bazı Tarımsal Özelliklerinin Belirlenmesi. Selçuk Üniversitesi Selçuk Gıda ve Tarım Bilimleri Dergisi, 23(49) : 67-73.

Çakmak F, Azkan N, Kaçar O, Çöplü N (1999) Bazı Kuru Fasulye Hatlarının Agronomik Özellikleri ile Verim Potansiyellerinin Saptanması. Türkiye 3. Tarla Bitkileri Kongresi, 15-18 Kasım 1999, Adana, 354-359.

Çalışkan S (2014) TR71 Bölgesinde Fasulye Tarımının Mevcut Durumu, Sorunları ve Çözüm Önerileri. Türk Tarım-Gıda Bilim ve Teknoloji Dergisi, 2(2) : 60-65.

Çiftçi CY, Şehirali S (1984) Fasulye (Phaseolus vulgaris L.) Çeşitlerinde Değişik Özelliklerin Fenotipik ve Genotipik Farklılıklarının Saptanması. Ankara Üniversitesi Fen Bilimleri Enstitüsü Yayın No: TB 4. Ankara.

Demircan Ş (2018) Yüksek Tane Verimli Kuru Fasulye Hatlarının Geliştirilmesi. Yüksek Lisans Tezi, Selçuk Üniversitesi Fen Bilimleri Enstitüsü, Konya.

Düzdemir O, Akdağ C (2001) Türkiye Kuru Fasulye (Phaseolus vulgaris L.) Gen Kaynaklarının Karakterizasyonu: II. Verim ve Diğer Bazı Özellikleri. Gaziosmanpaşa Üniversitesi Ziraat Fakültesi Dergisi, 18(1) : 101-105.

Elkoca E, Çınar T (2015) Bazı Kuru Fasulye (Phaseolus vulgaris L.) Çeşit ve Hatlarının Erzurum Ekolojik Koşullarına Adaptasyonu, Tarımsal ve Kalite Özellikleri. Anadolu Tarım Bilimleri Dergisi, 30: 141153.

Elkoca E, Kantar F (2004) Erzurum Ekolojik Koşullarına Uygun Erkenci ve Yüksek Verimli Kuru Fasulye (Phaseolus vulgaris L.) Genotiplerinin Belirlenmesi. Atatürk Üniversitesi Ziraat Fakültesi Dergisi, 35(3-4) : 137-142.

İyigün T, Kayan N (2019) Bazı Fasulye Genotiplerinin Eskişehir Koşullarına Uyum Yetenekleri. Akademik Ziraat Dergisi 8(2) : 291-300.

Karasu A (1988) Bursa Yöresinde Yetiştirilen Bazı Fasulye (Phaseolus vulgaris L.) Çeşitlerinin Önemli Tarımsal Özellikleri Üzerinde Araştırmalar. Yüksek Lisans Tezi, Uludağ Üniversitesi Fen Bilimleri Enstitüsü, Bursa. 
Kün E, Çiftçi GY, Birsin $M$, Ülger AC, Karahan S, Zencici N, Öktem A, Güler M, Yılmaz N, Atak M (2005) Tahıl ve Yemeklik Dane Baklagil Üretimi: Yemeklik Dane Baklagiller. Türkiye Ziraat Mühendisliği V. Teknik Kongresi, 3-7 Ocak 2005, Ankara, 396-407.

Kwak M, Gepts P (2009) Structure of Genetic Diversity in The Two Major Gene Pools of Common Bean (Phaseolus vulgaris L., Fabaceae). Theor. Appl. Genet., 118 : 979-992.

Önder M, Şentürk D (1996) Ekim Zamanlarının Bodur Kuru Fasulye Çeşitlerinde Dane ve Protein Verimi ile Verim Unsurlarına Etkisi. Selçuk Üniversitesi Ziraat Fakültesi Dergisi, 10(3) : 7-18.

Özçelik H, Sözen Ö (2009) Kelkit Vadisi Yerel Fasulye (Phaseolus vulgaris L.) Populasyonlarının Toplanması, Karakterizasyonu, Morfolojik ve Agronomik Değiskenliklerin Belirlenmesi. Proje No: 1080013. 80s. Ankara.

Paunovic MMAS, Bokan N, Veljkovic B (2006) Grain Yield of New Malting Barley Cultivars in Different Agroecological Conditions. Acta Agriculturae Serbica, Vol. XI, 22: 29-35.

Pekşen E (2005) Samsun Koşullarında Bazı Fasulye (Phaseolus vulgaris L.) Genotiplerinin Tane Verimi ve Verimle İlgili Özellikler Bakımından Karşılaştırılması.
Ondokuz Mayıs Üniversitesi Ziraat Fakültesi Dergisi, 20(3) : 88-95.

Pekşen E, Artık C (2005) Anti Besinsel Maddeler ve Yemeklik Tane Baklagillerin Besleyici Değerleri. Ondokuz Mayıs Üniv. Ziraat Fakültesi Dergisi, 20(2): 110-120.

Pekşen E, Gülümser A (2005) Bazı Fasulye (Phaseolus vulgaris L.) Genotiplerinde Verim ve Verim Unsurları Arasındaki İlişkiler ve Path Analizi. Ondokuz Mayıs Üniversitesi Ziraat Fakültesi Dergisi, 20(3) : 82-87.

Shinde SS, Dumbre AD (2001) Correlation and Path Coefficient Analysis in French Bean. Journal of Maharashtra Agricultural Universitie, 26(1) : 48-49.

Sözen Ö (2012) Kelkit Vadisi ve Artvin Iili'nden Toplanan Yerel Fasulye (Phaseolus vulgaris L.) Populasyonlarından Teksel Seleksiyon Metodu ile Şeker tane Tipinde Çeşit Geliştirilmesi Üzerine Bir Araştırma. Doktora Tezi, Ondokuz Mayıs Üniversitesi Fen Bilimleri Enstitüsü, Tarla Bitkileri Anabilim Dalı, Samsun.

Şehirali S (1980) Bodur Fasulyede Ekim Sıklığının Verimle İlgili Bazı Karakterler Üzerine Etkisi. Ankara Üniversitesi Ziraat Fakültesi Yayınları: 738 (Bilimsel Araştırma ve İncelemeler: 429), 55. Ankara.

Şehirali S (1988) Yemeklik Tane Baklagiller. Ankara Üniversitesi Ziraat Fakültesi Yayınları: 1089, Ders Kitabı: 314- 435, Ankara. 